\title{
INTERNALISASI NILAI-NILAI KARAKTER PADA PEMBELAJARAN PENDIDIKAN AGAMA ISLAM (PAI) DI SMP NEGERI 4 SUNGAI RAYA
}

\author{
Purwaningsih, Rianawati dan Kartini \\ IAIN Pontianak, Indonesia \\ icalicoel@gmail.com
}

\begin{abstract}
This research conducted because of the gap between what is done by Islamic religious education teachers in the process of internalizing the character values carried out by the teacher towards studentsespecially in the preparation of lesson plan This study used descriptive method with a qualitative approach. The technique of checking the validity of the data using triangulation and member check. Based on the results of the data obtained by the researchers, the following conclusions are produced: 1) internalization of the preliminary activities with the character values of discipline, religious, social care and discipline, curiosity, independence, communicative, 2) internalization of the core learning activities emphasize the process the formation of students' learning experiences in certain subject matter/material; and 3) internalization of the final activity by means of the teacher concludes the lesson that has been delivered (the character value is creative, cooperative and communicative) then the teacher evaluates at the end of the learning (the character value is independent, creative and responsible) provides the final motivation for students (character value is curiosity and respect for achievement) then reads the prayer and ends with greeting (the value of the character is religious).
\end{abstract}

Keywords: Internalization of Character Values, Islamic Religious Education, SMPN 4

\begin{abstract}
Abstrak: Penelitian ini terjadi karena adanya kesenjangan antara apa yang dilakukan oleh guru pendidikan agama Islam dalam proses internalisasi nilai-nilai karakter yang dilakukan guru terhadap siswa. terutama dalam penyusunana RPP. Penelitian ini menggunakan metode deskriptif dengan pendekatan kualitatif. Tehnik pengecekan keabsahan data menggunakan triangulasi dan member check.Berdasarkan hasil data yang diperoleh peneliti, menghasilkan kesimpulan sebagai berikut: 1) internalisasi pada kegiatan pendahuluan dengan nilai karakter disiplin, religius, peduli sosial dan disiplin, rasa ingin tahu, mandiri, komunikatif;2) internalisasi pada Kegiatan inti pembelajaran ini lebih menekankan pada proses pembentukan pengelaman belajar (learning experience) siswa dalam materi/bahan pelajaran tertentu; dan 3) internalisasi pada kegiatan akhir dengan cara guru menyimpulkan pelajaran yang telah disampaikan (nilai karakter adalah kreatif,kerja sama dan komunikatif) kemudian guru melakukan evaluasi di akhir pembelajaran (nilai karakter adalah mandiri,kreatif dan tanggung jawab) memberikan motivasi akhir kepeserta didik (nilai karakter adalah rasa ingin tahu dan menghargai prestasi) lalu membaca doa dan di akhiri dengan mengucap salam (nilai karakter adalah religius).
\end{abstract}

Kata Kunci: Internalisasi Nilai-Nilai Karakter, Pendidikan Agama Islam, SMPN 4 


\section{A. Pendahuluan}

Pendidikan adalah usaha sadar dan terencana untuk mewujudkan suasana belajar dan proses pembelajaran agar peserta didik secara aktif mengembangkan potensi dirinya untuk memiliki kekuatan spiritual keagamaan, pengendalian diri, kepribadian, kecerdasan, akhlak mulia, serta keterampilan yang diperlukan dirinya, masyarakat, bangsa dan negara yang mana diamanatkan dalam membentuk perilaku manusia, pendidikan memiliki peran penting bahkan menjadi kunci utama.

Salah satu aspek yang harus diperhatikan dalam pendidikan adalah karakter yang merupakan nilai-nilai perilaku manusia yang berhubungan dengan Tuhan Yang Maha Esa, diri sendiri, sesama manusia, lingkungan, dan kebangsaan yang terwujud dalam pikiran, sikap, perasaan, perkataan, dan perbuatan berdasarkan norma-norma agama, hukum, tata krama, budaya, dan adat istiadat 222 . Aspek lainnya yang banyak disoroti adalah menyangkut aspek muatan kurikulum, sarana pendidikan, di dalamnya buku-buku dan bahan materi pendidikan bahan ajar. Dengan demikian perlu dicari suatu bentuk perbaikan dengan strategi tepat untuk mengatasi adanya kesenjangan penerapan akhlak secara keseluruhan.

Pembiasaan-pembiasaan untuk melibatkan anak di dalam memecahkan masalah tidak sekedar melatih kemampuan berfikir dan mengajarkan cara pemecahan masalah, akan tetapi tujuan yang lebih subtansial adalah menanamkan pemahaman kepada anak-anak bahwa ada mekanisme yang baik melalui tanya jawab. Dalam proses komunikasi, guru memberi contoh dan menunjukkan bagaimana belajar mendengar pendapat orang lain. Pendidikan karakter adalah suatu sistem penanaman nilai-nilai karakter kepada warga sekolah yang meliputi komponen pengetahuan, kesadaran atau kemauan dan tindakan untuk melaksanakan nilai-nilai tersebut. Jadi, pada dasarnya bahwa pendidikan karakter itu adalah segala sesuatu yang dilakukan oleh guru yang

222 Emilia Setyoningtyas, Kamus lengkap Bahasa Indonesia, (Surabaya: Apollo Lestari, 2008), hlm. 152. 
mampu mempengaruhi karakter peserta didik. Sekolah merupakan lembaga pendidikan karakter salah satu cara penanaman nilai-nilai karakter melalui pembelajaran. Pentingnya pendidikan karakter dalam pembelajaran Pendidikan Agama Islam (PAI) pentingnya pembentukan karakter pada diri peserta didik maka peneliti tertarik untuk menyajikan kajian tentang internalisasi pendidikan karakter kepada peserta didik dalam PAI, yang diharapkan dari itu pula nantinya dapat tertanam kesadaran berperilaku sesuai dengan kaidah moral, etika, dan akhlak sesuai ajaran agama Islam. Setidaknya dari apa yang telah ada menjadi sesuatu yang perlu dikaji bagaimana pelaksanaan, strategi, dan isi atau materi yang digunakan dalam proses pembelajaran PAI sebagai alternatif pendidikan untuk mewujudkan investasi masa depan generasi bangsa yang unggul dan cakap serta memiliki perangai yang mulia.

Namun pada kenyataannya masih banyak guru PAI yang masih mengutamakan pengetahuan kognitif ketimbang aspek afektif dan psikomotorik dalam pembelajaran. Maka dalam hal ini guru harus benar-benar memperhatikan dalam perencanaan pembelajaran, pelaksanaan kegiatan belajar mengajar dan penilaian hasil belajar PAI terhadap peserta didik dengan meginternalisasi nilai-nilai karakter. Maka, kegiatan pembelajaran dari tahapan kegiatan awal, inti dan penutup harus dipilih dan dilaksanakan dengan baik agar peserta didik mampu mempraktikkan nilai-nilai karakter yang ditargetkan. Dan perlu digaris bawahi bahwa perilaku sepanjang proses pembelajaran harus menjadi model pelaksanaan nilai-nilai karakter bagi peserta didik karena guru merupakan sentral serta sumber kegiatan belajar mengajar. Adanya kesenjangan antara apa yang dilakukan oleh guru pendidikan agama Islam di SMPN 4 kuburaya dalam proses internalisasi nilainilai karakter yang dilakukan guru terhadap siswa. Terutama dalam penyusunan RPP, hal ini terlihat dari RPP223.

\footnotetext{
${ }^{223}$ Berdasarkan hasil observasi di SMP Negeri 4 Kecamatan Sungai Raya pada tanggal 17 Maret 2018.
} 
Guru menginternalisasi nilai-nilai karakter pada proses pembelajaran khususnya pada kegiatan pendahuluan, inti dan akhir. Selain itu, peneliti juga menemukan fenomena yang terjadi dalam proses pembelajaran PAI dimana pada saat proses pembelajaran dimana pada tahap internalisasinya didominasi pada penerapan kognitif saja, siswa hanya memahami materi saja yang berakibat nilai karakter kreatif, percaya diri terabaikan. Hal ini terlihat dari prilaku siswa yang tidak serius ketika dalam proses pembelajaran, sering tertawa dan begurau ketika guru menjelaskan, dan mengeluarkan kata-kata kasar terhadap sesama temannya dan tidak menghargai guru ketika dalam proses pembelajaran.

Oleh karena itu, guru melihat kondisi tersebut khususnya guru PAI memberikan teguran atau nasehat kepada siswa tersebut. Hal seperti itu perlu diperhatikan oleh guru dalam membentuk karakter siswa melalui pembiasaan, ataupun melalui penanaman nilai-nilai karakter siswa. Adapun alasan menjatuhkan pilihan peneliti ini pada mata pelajaran pendidikan agama Islam, karena peneliti ingin memberikan kontribusi positif terhadap pengembangan pendidikan agama Islam dalam perannya membangun religiusitas peserta didik yang memberikan dampak positif terhadap penguatan karakter yang tercermin dari sikap tingkah laku peserta didik.

\section{B. Metode Penelitian}

Penelitian ini merupakan penelitian kualitatif yaitu prosedur penelitian yang menghasilkan data deskriptif berupa kata - kata tertulis atau lisan dari orang-orang dan perilaku yang dapat diamati. Penelitian ini ditujukan untuk memahami fenomena-fenomena sosial dari sudut atau perspektif partisipan. Partisipan adalah orang- orang yang diajak wawancara, diobservasi, dimintai memberikan data, pendapat, pemikiran, persepsinya. Kualitaitf adalah prosedur penelitian yang menghasilkan data deskriptif berupa kata-kata tulisan atau lisan dari orang-orang dan perilaku yang sedang diamati 224 . Penelitian 
kualitatif adalah tradisi tertentu dalam ilmu pengetahuan sosial yang secara fundamental bergantung kepada pengamatan terhadap manusia dalam bahasanya dan dalam peristiwanya. ${ }^{225}$

Peneliti akan menganalisis proses pembelajaran pendidikan agama Islam yang sedang berlangsung dengan menggunakan observasi lapangan tanpa mengikuti proses pembelajaran secara langsung. Kemudian hasil analisis tersebut akan dideskripsikan secara mendetail terkait proses pembelajaran hingga akan diperoleh berbagai kemungkinan integrasi nilai-nilai karakter dalam pembelajaran pendidikan agama Islam di SMP N 04 Sungai Raya. Lokasi penelitian di SMP Negeri 4 Sungai Raya letaknya jalan Raya Desa Mekar Baru, Kecamatan Sungai Raya, Kabupaten Kubu Raya Provinsi Kalimantan Barat. Berdasarkan hasil penelitian, di SMP Negeri 4 Sungai Raya, yang mempunyai kompetensi dalam mengembangkan pendidikan karakter diantaranya adalah pelajaran Pendidikan Agama Islam (PAI) yang sekarang sedang dijalan kan.

Sumber data dalam penelitian ini adalah data yang diperoleh dari beberapa sumber diantaranya, kepala sekolah yang memiliki gagasan pertama mengenai penanaman nilai-nilai karakter, siswa dan guru pendidikan agama Islam yang menjadi pelaku langsung dalam proses pembelajaran. Jika pengumpulan data menggunakan kuesioner atau wawancara maka sumber datanya disebut dengan responden, begitu pula jika pengumpulan data dengan observasi maka sumber datanya benda baik benda mati maupun bergerak, sedangkan dengan dokumentasi sumber datanya dapat berupa catatan atau dokumen-dokumen.

\section{Dasar Pendidikan Karakter Dalam Islam}

Pendidikan Islam adalah bimbingan jasmani dan rohani berdasarkan hukum-hukum Islam untuk menuju terbentuknya kpribadian utama menurut ukuran-ukuran Islam. ${ }^{226}$ Pendidikan sebagai usaha dalam membina dan 40.

${ }^{225}$ Lexy J. Moloeng, Metode Penelitian Kualitatif, (Bandung: Remaja Rosdakarya, 2005), hlm. 226 Ahmad Marimba, Pengantar Filsafat Pendidikan Islam, (Bandung: Al-Ma'rif, 1962), hlm. 23. 
mengembangkan pribadi manusia dari aspek-spek rohaniah dan jasmaniah juga harus berlangsung secara bertahap. Selain itu, pendidikan adalah usaha orang tua sesuai dengan ajaran agama sehingga anak mereka nantinya memiliki ilmu pengetahuan dan akhlak mulia. Dan pendidikan agama Islam juga merupakan usaha yang dapat dilakukan seseorang atau lembaga pendidikan secara sadar untuk mengembangkan potensi siswa, baik yang bersifat jasmani maupun rohani berdasarkan ajaran Islam.

Dasar pendidikan Islam adalah segala ajarannya yang bersumber dari alQuran, Sunnah dan Ijtihad. Dasar inilah yang membuat pendidikan Islam menjadi ada, tanpa dasar ini tidak akan ada pendidikan Islam. Menurut Zuhairini, dasar religius adalah dasar-dasar yang bersumber dari ajaran agama Islam yang tertera dalam al-Quran maupun As-Sunnah. Istilah-istilah yang sering biasa digunakan dalam membicarakan ilmu tentang syari'ah ini maka dapat di tarik kesimpulan bahwa tujuan akhir dari mata pelajaran PAI adalah terbentuknya peserta didik yang memiliki akhlak yang mulia (budi pekerti yang luhur). Sunnah berisi petunjuk (pedoman) untuk kemaslahatan hidup manusia dalam segala aspeknya, untuk membina umat menjadi manusia seutuhnya atau muslim yang bertaqwa. Untuk itu Rasulullah menjadi guru dan pendidik utama bagi umatnya. 227

Tujuan pendidikan Islam adalah jika berbicara mengenai tujuan pendidikan Islam, berarti berbicara tentang nilai-nilai ideal yang bercorak Islami. $228 \mathrm{Hal}$ ini mengandng makna bahwa tujuan pendidikan Islam adalah tujuan merealisasikan idealitas Islam. Sedangkan idealitas Islam itu sendiri pada hakikatnya adalah mengandung nilai prilaku manusia yang didasari oleh iman dan taqwa kepada Allah sebagai sumber kekuasaan mutlak yang harus ditaati. Oleh karena itu, pendidikan Islam harus memasukkan nilai kemanusiaan dan karakter sehingga dapat memperbaiki akhlak manusia

227 Zakiah Darajat, Pendidikan Islam dalam Keluarga dan Sekolah, Cet. II, (Jakarta: Ruhama, 2004), hlm. 19.

228 Roetiyah, Strategi Belajar Mengajar, (Jakarta: PT Rineka Cipta, 2008), hlm. 9. 
karena banyak sekali hasil Pendidikan Agama Islam yang tidak berkorelasi positif terhadap tingkat ketaatan beragama. 229

\section{D.Nilai-Nilai Karakter Pada Pembelajaran Pendidikan Agama Islam}

Internalisasi diartikan sebagai penghayatan, penugasan, penguasaan secara mendalam yang berlangsung melalui pembinaan, bimbingan, penyuluhan, penataran, dan sebagainya. Internalisasi adalah menyatukan nilai dalam diri seseorang, atau dalam bahasa psikologi merupakan penyesuaian keyakinan, nilai, sikap, prilaku (tingkah laku), praktik aturan baku kepada diri seseorang. Internalisasi tidak terjadi begitu saja, namun melalui proses seperti bimbingan, binaan dan sebagainya sehingga nilai-nilai yang didapat dari proses internalisasi akan lebih mendalam dan tertananam didalam diri.

Sedangkan nilai diuraikan dalam dua gagasan yang saling berseberangan. Di satu sisi, nilai dibicarakan sebagai nilai ekonomi yang disandarkan pada nilai produk, kesejahteraan, dan harga, dengan penghargaan yang demikian tinggi pada hal yang bersifat material. Sementara disisi lain, nilai digunakan untuk mewakili gagasan atau makna yang abstrak dan tidak terukur dengan jelas. Nilai yang abstrak yang sulit di ukur itu, antara lain keadilan, kejujuran, kebebasan, kedamaian, dan persamaan ${ }^{230}$. Sedangkan istilah karakter secara harpiah berasal dari bahasa latin "charakter" yang antara lain berarti watak, tabiat, sifat-sifat kejiwaan, budi pekerti, keperibadian atau akhlak. Sedangkan secara istilah, karekter dapat diartikan sebagai sifat manusia pada umumnya, di mana manusia mempunyai banyak sifat yang tergantung dari faktor kehidupannya sendiri231. Pendidikan karakter adalah usaha sengaja (sadar) untuk membantu manusia memahami, peduli tentang, dan melaksanakan nilai-nilai etika inti. Karakter yang baik didukung oleh

\footnotetext{
229 Syukur Fatah, "Reorientasi Manajemen Pembelajaran Pendidikan Agama Islam (PAI) dan Deradikalisasi Agama," dalam Jurnal Penelitian Sosial Keagamaan, Vol. 23 No. 1, 2015, hlm. 15. 60.

230 Sofyan Sauri dan Herlan Firmansyah, Pendidikan Nilai, (Bandung: Arfino Raya, 2010), hlm. 231 Ahmad Husen, dkk., Model Pendidikan Karakter Bangsa, Jakarta: PT Rosdakarya, 2010, hlm. 6.
} 
pengetahuan tentang kebaikan, keinginan untuk berbuat baik, dan melakukan perbuatan kebaikan. Pendidikan karakter adalah usaha sengaja (sadar) untuk mewujudkan kebajikan, yaitu kualitas kemanusiaan yang baik secara objektif, bukan hanya baik untuk individu perseorangan, tetapi juga baik untuk masyarakat keseluruhan. ${ }^{232}$ Produk yang dihasilkan dari internalisasi nilai-nilai karakter bangsa melalui Pendidikan Agama Islam adalah peserta didik yang memiliki kompetensi pada bidang akademik dan berkarakter kebangsaan sekaligus. ${ }^{233}$ Dan nilai-nilai karakter yang diinternalisasi dalam diri peserta didik adalah nilai religius, kejujuran, tanggung jawab, kesopanan, saling menghargai, peduli pada lingkungan dan cinta tanah air. ${ }^{234}$

\section{E. Internalisasi Nilai Karakter pada Pembelajaran PAI di SMP N 4 Sungai \\ Raya}

\section{Internalisasi Nilai Karakter pada Kegiatan Awal}

Kegiatan awal atau dikenal dengan pra-instruksional adalah pengkondisikan kegiatan pembelajaran yang bertujuan agar peserta didik berpartisipasi aktif sehingga proses pembelajaran menjadi kondusif. Berikut ini adalah beberapa yang dilakukan guru dalam kegiatan awal antara lain: memberikan salam, mengecek kehadiran peserta didik, memberikan apersepsi, prestest, dan motivasi awal. Berdasarkan pengamatan dan observasi dikelas PAI, nilai-nilai karakter yang dapat ditanamkan ke dalam diri siswa melalui kegiatan pendahuluan yaitu; disiplin, komunikatif dan tanggung jawab, religius, cinta damai dan peduli sosial dan rasa ingin tahu. ${ }^{235}$

Internalisasi nilai-nilai karakter pada kegiatan pendahuluan ialah dengan cara menyiapkan kondisi (Nilai karakter disiplin) guru mengucap

\footnotetext{
${ }^{232}$ Karakter berkaitan dengan konsep moral (moral knonwing), sikap moral (moral felling), dan perilaku moral (moral behavior).

233 Wibowo AM, "Internalisasi Nilai-nilai Karakter Bangsa Melalui Mata Pelajaran PAI pada SMA Eks RSBI di Pekalongan," dalam Journal of Social Science and Religion, Vol. 21, No. 2, 2014.

${ }^{234}$ Widyaningsih T.S., dkk., "Internalisasi Dan Aktualisasi Nilai-Nilai Karakter Pada Siswa Smp Dalam Perspektif Fenomenologis," dalam Jurnal Pembangunan Pendidikan Fondasi dan Aplikasi, Vol. 2 No. 2, 2014.

235 Rianawati, Integrasi Nilai-Nilai Karakter dalam Pendidikan Agama Islam (PAI) di Sekolah, (Pontianak: IAIN Press, 2007).
} 
salam dan membaca doa (Nilai karakter religius) guru mengecek kehadiran siswa (Nilai karakter peduli sosial dan disiplin), guru menyampaiakan tema dan tujuan pembelajaran (Nilai karakter rasa ingin tahu), guru melakukan appersepsi dan pre-tes (Nilai karakter, mandiri, komunikatif), serta guru memberikan memotivasi awal kepada siswa dengan cara memberi dorongan kepada siswa untuk giat belajar (Nilai karakter, rasa ingin tahu). ${ }^{236}$

\section{Internalisasi Nilai Karakter pada Kegiatan Inti}

Pada prinsipnya kegiatan inti dalam pembelajaran adalah suatu proses pembentukan pengalaman dan kemampuan siswa serta terprogram yang dilaksanakan dalam durasi waktu tertentu. Pelaksanaan kegiatan inti merupakan proses pembelajaran untuk mencapai Kompetensi Dasar (KD) yang dilakukan secara interaktif, inspiratif, menyenangkan, menantang, memotivasi peserta didik untuk berpatisipasi aktif, serta memberikan ruang yang cukup bagi prakarsa, kreativitas, dan kemandirian sesuai dengan bakat, minat dan perkembangan fisik serta psikologis peserta didik.

Lebih lanjut, kegiatan inti pembelajaran ini lebih menekankan pada proses pembentukan pengelaman belajar (learning experience) siswa dalam materi atau bahan pelajaran tertentu, yang disusun dan direncanakan oleh guru berdasarkan pada kurikulum yang berlaku. Selain itu juga kegiatan inti menggunakan metode yang disesuaikan dengan karakteristik peserta didik dan mata pelajaran, yang meliputi proses ekspolarasi, elaborasi dan konfirmasi. 237

Eksplorasi nilai karakter yang ditanamkan melalui proses transformasi nilai, transaksi nilai dan transinternalisasi kegiatan menjelaskan materi (nilai karakter, disiplin, kerja keras, tanggung jawab, kejujuran, amanah, istiqomah, berdasarkan sifat nabi, yaitu: sidiq (jujur), amanah (dapat dipercaya), fathonah (cerdas), tabligh (menyampaikan), melibatkan siswa mencari informasi yang luas tentang materi yang disampaikan (nilai karakter mandiri), dan interaksi

236 Qomarudiin, "Implementasi Nilai-Nilai Pendidikan Karakter dalam Pembelajaran Pendidikan Agama Islam," dalam Jurnal Ilmu Pendidikan Islam, Vol. 16, No. 2, 2016, hlm. 13.

237 Toto Ruhimat, Prosedur Pembelajaran, (Bandung: Diretori UPI, 2012), hlm. 16. 
antara guru dan siswa (nilai karakter saling menghargai), Interaksi siswa dan lingkungan dan sumber belajar (nilai karakter saling menghargai), aktifitas siswa dalam belajar (nilai karakter, rasa percaya diri dan mandiri). ${ }^{238}$ Elaborasi nilai karakter yang dtanamkan melalui proses transformasi nilai, transaksi nilai dan transinternalisasi. Membiasakan siswa membaca dan menulis melalui tugas (nilai karakter kreatif dan logis), pemberian tugas secara lisan maupun tulisan (nilai karakter kreatif dan percaya diri), memberikan kesempatan siswa untuk berpikir, menganaisis dan menyelesaikan masalah dan bertindak tanpa rasa takut (nilai karakter adalah percaya diri, kritis dan kreatif), berkompensi secara sehat (nilai karakter jujur dan saling menghargai).

Konfirmasi nilai karakter yang ditanamkan melalui proses transformasi nilai, transaksi nilai dan transinternalisasi nilai, memberi umpan balik positif dan penguatan (nilai karakter saling menghargai, percaya diri), memberi konfirmasi terhadap hasil eksplorasi dan elaborasi (nilai karakter percaya diri, logis dan kritis), memberi membimbing siswa mengecek hasil eksplorasi (nilai karakter adalah percaya diri, logis dan kritis), memberikan motivasi (nilai karakter peduli sosial dan percaya diri).

\section{Internalisasi Nilai Karakter pada Kegiatan Akhir}

Kegiatan akhir dalam pembelajaran tidak hanya diartikan sebagai kegiatan untuk menutup pelajaran, tetapi juga sebagai kegiatan penilaian hasil belajar siswa dan kegiatan tindak lanjut.239 Kegiatan tindak lanjut harus ditempuh berdasarkan pada proses dan hasil belajar siswa. Internalisasi nilainilai karakter pada kegiatan akhir ialah ialah dengan cara guru menyimpulkan pelajaran yang telah disampaikan (nilai karakter adalah kreatif, kerja sama dan komunikatif) kemudian guru melakukan evaluasi di akhir pembelajaran (nilai karakter adalah mandiri, kreatif dan tanggung jawab) memberikan motivasi akhir kepeserta didik (nilai karakter adalah rasa ingin tahu dan menghargai prestasi) lalu membaca doa dan di akhiri dengan mengucap salam (nilai

\footnotetext{
238 Qomarudiin, “Implementasi Nilai-Nilai....., hlm. 16.

239 Ruhimat, Prosedur Pembelajaran, hlm. 38.
} 
karakter adalah religius). ${ }^{240}$ Strategi internalisasi nilai-nilai karakter pada kegiatan akhir setelah melakukan pelajaran Pendidikan Agama Islam yaitu memberi motivasi akhir ketika memberikan motivasi pada kegiatan akhir proses pembelajaran mata pelajaran PAI yaitu terus memberikan dorongan kepada siswa untuk terus belajar serta membangkitkan rasa ingin tahu siswa.

Banyak kesulitan yang masih ditemui dalam menginternalisasi nilai-nilai karakter ada beberapa siswa, karena masih ada beberapa siswa, yang tidak menanamkan nilai karakter rasa ingin tahu, komunikatif dan mandiri ketika melakukan appersepsi dalam pembelajaran tersebut. Cara untuk mengatasi berbagai kesulitan dalam menginternalisasi menanamkan nilai-nilai karakter yang dapat dilakukan dalam mengatasi kesulitan yaitu menanamkan karakter rasa ingin tahu agar siswa tersebut mengetahui betapa pentingnya melakukan appersepsi pada proses pembelajaran karena memberi dorongan kepada siswa agar siswa bersemangat dan giat lagi dalam belajar

Nilai karakater yang ditanamkan dalam melibatkan siswa mencari informasi yang luas tentang materi yang disampaikan adalah kerja sama dan mandiri. Nilai-nilai karakter yang ditanamkan dalam interaksi antara guru dan siswa adalah saling menghargai. Nilai-nilai karakter yang ditanamkan dalam interaksi siswa dan lingkungan dan sumber belajar adalah kerja sama dan saling menghargai. Nilai-nilai karakter yang ditanamkan dalam aktifitas siswa dalam belajar adalah rasa percaya diri dan mandiri, nilai-nilai karakter ini sangat perlu untuk ditanamkan agar siswa mengetahui bahwa setiap proses pembelajaran berlangsung yang telah dilaksanakan memiliki karakter yang berbeda.

\section{F. Kesimpulan}

Pendidikan karakter tidak dapat berdiri sendiri sebagai mata pelajaran karena ia harus diinternalisasikan dalam bidang studi lain, misalnya Pendidikan Agama Islam (PAI). Proses internalisasi nilai-nilai karakter bangsa

\footnotetext{
240 Qomarudiin, “Implementasi Nilai-Nilai......, hlm. 17.
} 
melalui mata pelajaran PAI dilakukan melalui kurikulum PAI berupa silabus dan rencana pelaksanaan pembelajaran, kegiatan interakurikuler dan ekstrakurikuler. produk yang dihasilkan dari internalisasi nilai-nilai karakter bangsa melalui Pendidikan Agama Islam adalah peserta didik yang memiliki kompetensi pada bidang akademik dan berkarakter kebangsaan sekaligus.

Hal lain yang juga penting dalam memberi umpan balik positif dan penguatan adalah dengan cara memberitahukan atas hasil yang telah dikerjakan oleh siswa baik jawaban yang benar ataupun salah, dan diberi kesempatan untuk memperbaiki yang salah dan bagi siswa yang berhasil diberikan penghargaan agar siswa tersebut lebih giat lagi dalam belajar. konfirmasi terhadap hasil eksplorasi dan elaborasi adalah dengan cara menanamkan sikap rasa percaya diri siswa terhadap hasil yang telah dikerjakan.tranformasi nilai dalam membimbing siswa mengecek hasil eksplorasi adalah menumbuhkan rasa percaya diri siswa atas hasil yang dikerjakan baik itu kelompok ataupun sendiri. tranformasi nilai dalam memberikan motivasi adalah memberitahukan siswa agar lebih giat lagi dalam belajar.

\section{DAFTAR PUSTAKA}

Marimba, Ahmad, Pengantar Filsafat Pendidikan Islam, Bandung: Al-Ma'rif, 1962.

Husen, Ahmad, dkk., Model Pendidikan Karakter Bangsa, Jakarta: PT Rosdakarya, 2010.

Q-Anees, Bambang dan Dadang Hambali, Pendidikan Karakter berbasis AlQur'an, Bandung: Simbiosa Rekatama Media, 2009.

Sulistyowati, Endah, Implementasi Kurikulum Pendidikan Karakter, Yokyakarta: PT Citra Aji Praman, 2012.

Setyoningtyas, Emilia, Kamus lengkap Bahasa Indonesia, Surabaya: Apollo Lestari. Mulyasa, E., Implementasi Kurikulum Tingkat Satuan Pendidikan, Jakarta: PT Bumi Aksara, 2008. 
Rianawati, Integrasi Nilai-nilai Karakter Dalam Pendidikan Agama Islam (PAI) di Sekolah, Pontianak: IAIN Press, 2007.

Roetiyah, Strategi Belajar Mengajar, Jakarta: PT Rineka Cipta, 2008.

Fatah, Syukur, "Reorientasi Manajemen Pembelajaran Pendidikan Agama Islam (PAI) dan Deradikalisasi Agama," dalam Jurnal Penelitian Sosial Keagamaan, Vol. 23, No. 1, 2015.

Sugiyono, Memahami Penelitian Kualitatif, Bandung: CV. Alfabeta, 2014.

Sauri, Sofyan dan Herlan Firmansyah, Pendidikan Nilai, Bandung: Arfino Raya, 2010.

Ruhimat, Toto, Prosedur Pembelajaran, Bandung: Diretori UPI, 2012.

Qomarudiin, "Implementasi Nilai-Nili Pendidikan Karakter Dalam Pembelajaran Pendidikan Agama Islam," dalam Jurnal Ilmu Pendidikan Islam, Vol. 16, No. 2, 2016.

Wibowo, AM, “Internalisasi Nilai-nilai Karakter Bangsa Melalui Mata Pelajaran PAI pada SMA Eks RSBI di Pekalongan," dalam Journal of Social Science and Religion, Vol. 21, No. 2, 2014.

Widyaningsih T.S, dkk., "Internalisasi Dan Aktualisasi Nilai-Nilai Karakter Pada Siswa Smp Dalam Perspektif Fenomenologis, "Jdalam urnal Pembangunan Pendidikan Fondasi dan Aplikasi, Vol. 2, No. 2, 2014.

Darajat, Zakiah, Pendidikan Islam dalam Keluarga dan Sekolah, Cet. II, Jakarta: Ruhama, 2004. 